\title{
Detection of peptide-specific CTL-precursors in peripheral blood lymphocytes of cancer patients
}

\author{
Y Maeda', ${ }^{1,2}$ N Hida', F Niiya', K Katagiri', M Harada', H Yamana ${ }^{3}$, T Kamura', M Takahashi ${ }^{2}$, Y Sato ${ }^{2}$, S Todo $^{2}$ \\ and $\mathrm{K}$ Itoh ${ }^{*, 1}$
}

'Department of Immunology, Kurume University, 67 Asahi-machi, Kurume, 830-00 I I, Japan; ${ }^{2}$ First Department of Surgery, Hokkaido University, NI 5-W7 Kita-ku, Sapporo 060-8638, Japan; ${ }^{3}$ Department of Surgery, Kurume University School of Medicine, 67 Asahi-machi, Kurume, 830-00 I I, Japan;

${ }^{4}$ Department of Obstetrics and Gynecology, Kurume University School of Medicine, 67 Asahi-machi, Kurume, 830-001 I, Japan

Development of therapeutic vaccines is one of the major areas of tumour immunotherapy today. However, clinical trials of peptide-based cancer vaccines have rarely resulted in tumour regression. This failure might be due to an insufficient induction of cytotoxic $T$ lymphocytes in the current regimes, in which cytotoxic $T$ lymphocytes-precursors in pre-vaccination peripheral blood mononuclear cells are not measured. Initiation of immune-boosting through vaccination could be better than that of immune-priming with regard to induction of prompt and strong immunity. If this is also the case for therapeutic vaccines, prevaccination measurement of peptide-specific cytotoxic $T$ lymphocytes-precursors will be important. In the present study, we investigated whether cytotoxic T lymphocytes-precursors reacting to 28 kinds of peptides of vaccine candidates ( 13 and 15 peptides for $\mathrm{HLA}-\mathrm{A} 24^{+}$and HLA-A2 ${ }^{+}$patients, respectively) were detectable in pre-vaccination peripheral blood mononuclear cells of 80 cancer patients. Peptide-specific cytotoxic T lymphocytes-precursors were found to be detectable in peripheral blood mononuclear cells of the majority of cancer patients (57 out of 80 cases, $71 \%$ ). The mean numbers of positive peptides were 2.0 peptides per positive case. Peripheral blood mononuclear cells incubated with positive peptides, not with negative peptides, showed significant levels of HLA-class-I-restricted cytotoxicity to cancer cells. The profiles of positive peptides entirely varied among patients, and were not influenced by the cancer origin. These results may provide a scientific basis for the development of a new approach to cancer immunotherapy, e.g.) cytotoxic $T$ lymphocytes-precursororiented peptide vaccine.

British Journal of Cancer (2002) 87, 796-804. doi:I0.1038/sj.bjc.6600548 www.bjcancer.com

(C) 2002 Cancer Research UK

Keywords: immunotherapy; cancer; peptide vaccine; CTL-precursors; pre-vaccination

Recent advances in molecular biology and tumour immunology have allowed for identification of a large number of genes and antigenic peptides recognised by cytotoxic $\mathrm{T}$ lymphocytes (CTLs), thereby introducing the possibility of a peptide-based cancer vaccine (Bruggen et al, 1991; Kawakami et al, 1994; Fisk et al, 1995; Correale et al, 1998). Preventive vaccine protocols for pathogenic microbes generally consist of three steps; priming, boosting and challenging (Amara et al, 2001). It usually takes several months for priming, which is consistent with the present results of our clinical trial using SART3-peptide vaccine (Miyagi et al, 2001). Although increased CTL activity has been obtained in the majority of cancer patients vaccinated with the peptides, clinical responses have rarely been obtained in these patients in either previous studies of melanoma patients (Rosenberg et al, 1998; Marchand et al, 1999; Wang et al, 1999; Gajewski et al, 2001), or our study of epithelial cancer patients (Miyagi et al, 2001).

One explanation for the failure to obtain clinical responses would be the time-lag needed for priming of anti-tumour response, given that the expected survival of most advanced cancer patients under these regimens is $6-9$ months. Therefore, developing a new protocol for obtaining tumour regression in these cancer patients is necessary.

*Correspondence: K Itoh; E-mail: kyogo@med.kurume-u.ac.jp Received 25 March 2002; revised 3 July 2002; accepted 22 July 2002
One protocol might be a pre-vaccination measurement of peptidespecific CTL-precursors in the circulation of cancer patients, followed by administration of CTL-precursor-oriented peptide vaccine. This protocol may more rapidly increase CTL activity in post-vaccination peripheral blood mononuclear cells (PBMCs). Pre-vaccination measurement of CTL-precursors could also be an important factor in the generation of strong immune response, since Langerhans cells presenting peptides need to meet peptide-specific CTL-precursors within 2 days at the regional lymph nodes to activate CTLs (Janeway et al, 1999). Further, recent studies on memory $\mathrm{CD} 8^{+} \mathrm{T}$ cells suggest that the main effect of vaccine boosters is to increase the number of antigen-specific memory $\mathrm{T}$ cells to one that confers better protection (Kaech and Ahmed, 2001; Finn and Lotze, 2001; Stipdonk et al, 2001).

In the present study, we investigated whether peptide-specific CTL-precursors are detectable in pre-vaccination PBMCs from cancer patients, and report herein that CTL-precursors reacting to cancer-related peptides are detectable in prevaccination PBMCs of the majority of cancer patients.

\section{MATERIALS AND METHODS}

\section{Patients, cell lines, and peptides}

PBMCs were isolated from $20 \mathrm{ml}$ of heparinized blood of HLA$\mathrm{A} 24^{+}(n=55)$ and HLA $-\mathrm{A} 2^{+}(n=25)$ cancer patients (40 gastric, 15 
colon, 11 lung, seven gynaecological, three prostate cancers, and four melanomas) by means of Ficoll - Conray density gradient centrifugation as reported previously (Gomi et al, 1999). Among them, 56 patients had no distant metastases and 24 patients had distant metastases. No patient had undergone any immunotherapy or chemotherapy at least for 1 month before sampling. Complete informed consents were obtained from all patients. PBMCs were also obtained from 31 healthy volunteers $\left(20\right.$ HLA - A2 $4^{+}$and 11 HLA $\left.\mathrm{A} 2^{+}\right)$. HLA-class-I typing was performed on blood lymphocytes using the classical serological method, as reported previously (Gomi et al, 1999). The tumour cell lines used in this study are as follows: KWS (HLA-A0206/0206), SSTW9 (A2402/2601) gastric adenocarcinoma, Panc-1 (A0201/0206) pancreatic adenocarcinoma, and SW620 (A0201/2402) colon adenocarcinoma. PHA-activated normal $\mathrm{T}$ cells were also used as target. Peptides used in this study are listed in Table 1 for HLA-A24-restricted peptides, and in Table 2 for HLAA2-restricted peptides. All peptides except for Epstein-Barr virus (EBV)- and Influenza virus (Flu)-derived peptides are encoded by tumour-rejection antigens, and have the ability to induce HLAA24 or -A2-restricted CTLs specific to tumour cells in PBMCs of cancer patients, as reported previously (Shichijo et al, 1998; Gomi et al, 1999; Yang et al, 1999; Ito et al, 2000, 2001; Kawano et al, 2000; Nakao et al, 2000; Nishizaka et al, 2000; Harashima et al, 2001; Tamura et al, 2001). These peptides were purchased from Sawady Laboratory (Tokyo, Japan), and their purity was $>95 \%$.

\section{Detection of CTL-precursors}

A simple method was used to detect peptide-specific CTLs in PBMCs (Hida et al, 2002). PBMCs $\left(1 \times 10^{5}\right.$ cells per well) were incubated with $10 \mu \mathrm{M}$ of a peptide in wells of the u-bottom-type 96-well microculture plates (Nunc, Roskilde, Denmark) in $200 \mu \mathrm{l}$ of culture medium. The culture medium consisted of $45 \%$ RPMI-1640 medium, 45\% AIM-V ${ }^{\mathbb{R}}$ medium (GIBCO-BRL), $10 \%$ FCS, $100 \mathrm{U} \mathrm{ml}^{-1}$ of interleukin-2 (IL-2), and $0.1 \mu \mathrm{M} \mathrm{MEM}$ nonessential amino acid solution (GIBCO-BRL). Half of the medium was removed and replaced with the new medium containing a corresponding peptide $(20 \mu \mathrm{M})$ every 3 days. After incubation for 12 days, these cells were harvested and then tested for their ability to produce IFN- $\gamma$ in response to CIR-A2402 cells pre-loaded with either a corresponding peptide or HIV peptide (RYLRQQLLGI) as a negative control in HLA-A24 ${ }^{+}$PBMCs, or those in response to $\mathrm{T} 2$ cells pre-loaded with a corresponding or HIV peptide (SLYNTYATL) in HLA-A2 ${ }^{+}$PBMCs by an enzyme-linked immuno-sorbent assay (ELISA) (limit of sensitivity: $10 \mathrm{pg} \mathrm{ml}^{-1}$ ). All experiments were performed in quadricate assays. Detectable levels of CTL-precursors were judged as positive (the score is in bold in Tables) if the mean value of IFN- $\gamma$ production by the peptide-stimulated PBMCs in response to a corresponding peptide was significantly $(P<0.05)$ higher than that in response to control HIV peptide. A two-tailed Student $t$-test and Fisher's exact probability test were employed for the statistical analyses.

\section{Cyototoxicity assay of the peptide-induced CTLs}

The peptide-stimulated PBMCs were further incubated in the presence of feeder cells for 3 weeks in order to obtain a relatively large number of cells, and were tested for their cytotoxicity against various target cells by a standard $6 \mathrm{~h}{ }^{51} \mathrm{Cr}$-release assay. For an inhibition assay, the ${ }^{51} \mathrm{Cr}$-release assay was performed in the presence of $20 \mu \mathrm{g} \mathrm{ml}^{-1}$ of anti-CD8, -CD4, -HLA-class I (W6/ 32), or -HLA-class II (DR) mAb. A standard CTL precursor frequency analysis was performed in certain cases, and the detailed description of this method is reported elsewhere (Miyagi et al, 2001). Briefly, cells were incubated at 12.5, 25, 50, 100, 200 and 400 cells per well of 96 -well microculture plate in the presence of feeder cells. Cells from each well were harvested and tested at 9 to 15 days of culture in duplicate assay for their ability to produce IFN- $\gamma$ by recognition of peptide-pulsed target cells. The well was considered positive if it contained effector cells producing much higher levels $\left(>100 \mathrm{pg} \mathrm{ml}^{-1}\right)$ and also statistically significant levels $(P<0.05$ by Student $t$-test $)$ of IFN- $\gamma$ in response to CIRA2402 cells (or T2 cells for HLA-A2 cases) pre-loaded with a corresponding peptide as compared with those in response to CIRA2402 cells (or T2 cells) pre-loaded with control HIV peptide. Data were analysed by the minimum $\chi^{2}$ method with $95 \%$ confidence intervals, and the CTL precursor frequency was calculated by Taswell's method (Taswell, 1981).

\section{RESULTS}

\section{CTL-precursors in gastric cancer patients}

PBMCs of cancer patients ( $n=80 ; 40$ gastric, 15 colon, 11 lung, seven gynecological, three prostate cancers, and four melanomas) and healthy donors $(n=31)$ were tested for their reactivity to a corresponding peptide after stimulation with each peptide. Results regarding HLA-A24 $4^{+}(n=20)$ and $-\mathrm{A}^{+} \quad(n=20)$ gastric cancer patients are shown in Tables 1 and 2, respectively. PBMCs from 16 of 20 HLA-A $24^{+}$gastric cancer patients possessed CTLprecursors reactive to at least one of 13 peptides of vaccine candidates tested (Table 1). Among these 16 patients, five, one, three, six and one patients had CTL-precursors reactive to one, two, three, four and five peptides of vaccine candidates, respectively. The mean number of positive peptides was 2.8 per patient. Seven and six patients had CTL-precursors reactive to ART4 $_{75}$ and SART3 109 peptides, respectively. Four patients had detectable levels of CTL-precursors to SART2 ${ }_{899}$, SART3 ${ }_{315}$, $\mathrm{lck}_{208}$ and $\mathrm{lck}_{488}$ peptides. CTL-precursors to the other seven peptides were also detectable in several patients. The profile of positive peptides entirely varied in 16 patients. In contrast, CTL-precursors reactive to these peptides were undetectable in PBMCs of the remaining four cancer patients. It is of note that CTL-precursors reactive to either Flu- or EBV-peptide, taken as positive control peptide, were also undetectable in PBMCs from those four cancer patients.

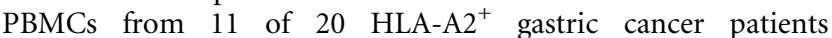
possessed CTL-precursors reactive to at least one of 15 peptides of vaccine candidates tested (Table 2). Among them, five, one, three, one and one patients had CTL-precursors reactive to one, two, three, four and seven peptides, respectively. The mean number of positive peptides was 2.3 peptides per patient. Four patients had CTL-precursors reactive to $\mathrm{HNRPL}_{140}$ peptide, while three patients had those reactive to $\mathrm{SART}_{302}$ and $\mathrm{SART}_{309}$ peptides. CTLprecursors were also found to the others except one $\left(\mathrm{ppMAPkkk}_{432}\right)$ peptide with lower frequencies. The profile of positive peptides was also entirely different among 11 patients. In contrast, CTL-precursors reactive to these peptides were undetectable in the remaining nine patients. Among them, seven patients had no detectable level of CTL-precursor reacting to either Fluor EBV-peptide.

\section{Cytotoxicity of peptide-induced CTLs}

A standard $6 \mathrm{~h}{ }^{51} \mathrm{Cr}$-release assay was employed to confirm the anti-tumour response of the peptide-induced CTLs in four cancer patients. PBMCs of Pt 2 (HLA-A24 $4^{+}$) showed significant levels of cytotoxicity against HLA-A24 ${ }^{+}$tumour cells (SW620 and SSTW9), but not against HLA-A24 ${ }^{-}$tumour cells (Panc1 and KWS) or normal PHA-blastoid T cells, when they were stimulated with each of the positive peptides derived from cancerrelated antigens (SART3 ${ }_{109}, \mathrm{lck}_{208}$, and $\mathrm{lck}_{488}$ ) (Figure $1 \mathrm{~A}$ and Table 3). In contrast, those stimulated with either EBV peptide 
Table I Induction of peptide-specific CTLs from PBMCs of HLA-A24+ gastric cancer patients

\begin{tabular}{|c|c|c|c|c|c|c|c|c|c|c|c|c|c|c|c|c|c|c|c|c|c|}
\hline \multirow[b]{3}{*}{ Peptide } & \multirow[b]{3}{*}{ Sequence } & \multicolumn{20}{|c|}{ Peptide-specific IFN- $\gamma$ production $\left(\mathbf{p g ~} \mathbf{~ m l}^{-1}\right.$ ) } \\
\hline & & \multirow[b]{2}{*}{ Pt I } & \multirow[b]{2}{*}{ Pt 2} & \multirow[b]{2}{*}{ Pt 3} & \multirow[b]{2}{*}{ Pt 4} & \multirow[b]{2}{*}{ Pt 5} & \multirow[b]{2}{*}{ Pt 6} & \multicolumn{7}{|c|}{ HLA-A24 ${ }^{+}$gastric cancer patients } & \multirow[b]{2}{*}{ Ptl4 } & \multirow[b]{2}{*}{ PtI5 } & \multirow[b]{2}{*}{ Pt16 } & \multirow[b]{2}{*}{ PtI7 } & \multirow[b]{2}{*}{ Pt18 } & \multirow[b]{2}{*}{ Pt19 } & \multirow[b]{2}{*}{ Pt20 } \\
\hline & & & & & & & & Pt 7 & Pt 8 & Pt 9 & PtI0 & PtII & Pt12 & PtI3 & & & & & & & \\
\hline Flu & RFYIQMCYEL & 0 & II & NT & 2 & 0 & 0 & 0 & 16 & 0 & 0 & 0 & 0 & 0 & 0 & 0 & 0 & 0 & 37 & 0 & 0 \\
\hline EBV & TYGPVFMCL & 0 & 392 & 11 & 16 & 6 & 0 & 0 & 15 & 0 & 0 & 0 & 244 & 10 & 0 & 11 & 0 & 0 & 109 & 0 & 0 \\
\hline SARTI 690 & EYRGFTQDF & 46 & 9 & 0 & 9 & 0 & 0 & 0 & 0 & 0 & 0 & 0 & 159 & 0 & 0 & 30 & 94 & 0 & 0 & 21 & 5 \\
\hline SART2 93 & DYSARWNEI & 0 & 24 & NT & 31 & 15 & 0 & 0 & 0 & 13 & 0 & 0 & 0 & 0 & 0 & 21 & 0 & 127 & 0 & 156 & 0 \\
\hline SART2 161 & AYDFLYNYL & 0 & 0 & NT & 0 & 18 & 911 & 0 & 0 & 0 & 19 & 0 & 146 & 2 & 0 & 0 & 170 & 0 & 0 & 12 & 0 \\
\hline SART2 899 & SYTRLFLIL & 0 & 0 & NT & 4 & 142 & 42 & 0 & 0 & 0 & 0 & 0 & 38 & 330 & 0 & 0 & 96 & 0 & 0 & 208 & 0 \\
\hline SART3 109 & VYDYNCHVDL & 65 & 375 & 240 & 53 & 0 & 218 & 0 & 258 & 0 & 0 & 0 & 26 & 34 & 0 & 0 & 0 & 25 & 93 & 69 & 0 \\
\hline SART3 $_{315}$ & AYIDFEMKI & 17 & 0 & 2 & 18 & 31 & 0 & 0 & 285 & 0 & 0 & 13 & 0 & 25 & 0 & 15 & 11 & 113 & 102 & 350 & 0 \\
\hline СуB 84 & KFHRVIKDF & 123 & 0 & 4 & 70 & 17 & 0 & 60 & 0 & 0 & 0 & 0 & 19 & 37 & 0 & 0 & 0 & 0 & 0 & 64 & 0 \\
\hline CyB 91 & DFMIQGGDF & 0 & 0 & 0 & 0 & 0 & 0 & 3 & 0 & 0 & 0 & 0 & 0 & 626 & 0 & 0 & 0 & 0 & 0 & 76 & 0 \\
\hline Ick 208 & HYTNASDGL & 93 & 117 & 0 & 0 & 26 & 0 & 0 & 0 & 0 & 0 & 330 & 79 & 170 & 14 & 0 & 0 & 65 & 11 & 0 & 0 \\
\hline Ick 486 & TFDYLRSVL & 0 & 0 & 0 & 22 & 0 & 0 & 0 & 125 & 0 & 0 & 14 & 2 & 20 & 0 & 10 & 0 & 63 & 4 & 0 & 0 \\
\hline ICk 488 & DYLRSVLEDF & 0 & 181 & 0 & 147 & 0 & 14 & 0 & 0 & 11 & 0 & 27 & 28 & 0 & 151 & 0 & 66 & 0 & 8 & 0 & 0 \\
\hline ART4 $_{13}$ & AFLRHAAL & 0 & 0 & NT & 21 & 13 & 325 & 4 & 0 & 0 & 0 & 132 & 0 & 488 & 46 & 0 & 0 & 0 & 0 & 4 & 0 \\
\hline ART4 75 & DYPSLSATDI & 0 & 0 & NT & 113 & 0 & 266 & 4 & 331 & 0 & 0 & 58 & 18 & $13 \mid$ & 0 & 63 & 0 & 19 & 73 & 97 & 0 \\
\hline
\end{tabular}

EBV: Epstein-Barr virus; SART: squamous cell carcinoma antigen recognized by T cells; CyB: Cyclophilin B; ART: adenocarcinoma antigen recognized by T cells. PBMCs of HLA$\mathrm{A} 24^{+}$gastric cancer patients were tested for their reactivity to a corresponding peptide after stimulation with each peptide. Values represent the means of quadricate assays of IFN- $\gamma$ production $\left(\mathrm{pg} \mathrm{ml}^{-1}\right.$ ) by the effector PBMCs in response to CIR-A2402 cells pulsed with a corresponding peptide. Background IFN- $\gamma$ production in response to HIV peptide $\left(0-200 \mathrm{pg} \mathrm{ml}^{-1}\right)$ was subtracted. Detectable levels of CTL-precursors were judged as positive (the score is in bold figures in Tables) if the mean value of IFN- $\gamma$ production by the peptide-stimulated PBMCs in response to a corresponding peptide was significantly $(P<0.05$, by two-tailed student $t$-test) higher than that in response to HIV peptide. NT: Not tested.

Table 2 Induction of peptide-specific CTLs from PBMCs of HLA-A2 ${ }^{+}$gastric cancer patients

Peptide-specific IFN- $\gamma$ production (pg $\mathrm{ml}^{-1}$ )

HLA-A2 ${ }^{+}$gastric cancer patients

\begin{tabular}{|c|c|c|c|c|c|c|c|c|c|c|c|c|c|c|c|c|c|c|c|c|c|}
\hline Peptide & Sequence & Pt2 I & Pt22 & Pt23 & Pt24 & Pt25 & Pt26 & Pt27 & Pt28 & Pt29 & Pt30 & Pt3 I & Pt32 & Pt33 & Pt34 & Pt35 & Pt36 & Pt37 & Pt38 & Pt39 & $\mathbf{P t}$ \\
\hline Flu & GILGFVFTL & 0 & 8 & NT & NT & NT & NT & 0 & 110 & 268 & 37 & 560 & NT & NT & NT & $1500<$ & 0 & 15 & 316 & 478 & 101 \\
\hline EBV & GLCTLVAML & 0 & 356 & 35 & 7 & 55 & 28 & 79 & 0 & 36 & 0 & 0 & 0 & 405 & 14 & 323 & 23 & 0 & 83 & 849 & \\
\hline SART3 302 & LLQAEAPRL & 0 & 0 & 9 & 16 & 0 & 212 & 0 & । & 26 & 0 & 0 & 0 & 5 & 63 & 100 & NT & 14 & 777 & 0 & \\
\hline SART3 309 & RLAEYQAYI & 6 & 0 & 0 & 52 & 0 & 195 & 134 & 0 & 75 & 0 & 0 & 0 & 24 & 0 & 74 & NT & 13 & 3 & 0 & \\
\hline $\mathrm{CyB}_{129}$ & KLKHYGPGWV & 0 & 40 & NT & NT & 0 & 11 & 66 & 0 & 33 & 0 & 346 & NT & NT & 0 & 58 & 20 & 33 & 0 & 0 & \\
\hline $\mathrm{CyB}_{172}$ & VLEGMEV & 0 & 38 & 18 & 14 & 0 & 0 & 0 & 0 & 27 & 0 & 0 & 0 & 0 & 86 & 63 & NT & 17 & 12 & 0 & \\
\hline Ick 246 & KLVERLGAA & 0 & 20 & 16 & 0 & 0 & 0 & 210 & 73 & 30 & 8 & 0 & 0 & 0 & 0 & 33 & 38 & 29 & 0 & 0 & \\
\hline EIF4EBPI 51 & RIIYDRKFL & 0 & 0 & NT & NT & NT & 79 & 0 & 63 & 21 & 20 & 0 & NT & NT & NT & 14 & NT & 5 & 172 & 0 & \\
\hline ppMAPkkk 294 & GLLFLHTRT & NT & NT & 0 & 27 & 0 & 126 & 76 & 0 & 10 & 0 & NT & 91 & 14 & 0 & 19 & NT & 9 & 0 & 0 & \\
\hline ppMAPkkk 432 & DLLSHAFFA & NT & NT & 5 & 6 & 0 & 9 & 65 & 2 & 16 & 14 & NT & 4 & 4 & 8 & 0 & NT & 0 & 0 & 0 & \\
\hline WHSC2 103 & ASLDSDPWV & NT & NT & 16 & 0 & 0 & 33 & 20 & 0 & 9 & 207 & NT & 18 & 0 & 0 & 53 & NT & 28 & 0 & 0 & \\
\hline WHSC2 141 & ILGELREKV & NT & NT & 0 & 0 & 0 & I & 33 & 0 & 16 & 4 & NT & 5 & 15 & 0 & 53 & NT & 10 & 0 & 0 & \\
\hline UBE2V $_{43}$ & RLQEWCSVI & NT & NT & 0 & 5 & 0 & 56 & 110 & 25 & 96 & 28 & NT & 0 & 20 & 0 & 3 & NT & 12 & 29 & 0 & \\
\hline UBE2V $_{85}$ & LIADFLSGL & NT & NT & 85 & 13 & 0 & 206 & 24 & 0 & 16 & 81 & NT & 0 & 19 & 0 & 0 & NT & 0 & 0 & 0 & \\
\hline UBE2V 208 & ILPRKHHRI & NT & NT & NT & NT & NT & NT & 7 & 2 & 0 & 56 & NT & NT & NT & NT & NT & NT & 5 & 0 & 0 & \\
\hline HNRPL 140 & ALVEFEDVL & NT & NT & 100 & 13 & 0 & 17 & 0 & 57 & 22 & 63 & NT & 0 & 7 & 0 & 401 & NT & 0 & 0 & 0 & \\
\hline HNRPL 501 & NVLHFFNAPL & NT & NT & 8 & 0 & 6 & 0 & 6 & 0 & 0 & 5 & NT & 0 & 20 & 0 & 0 & NT & 0 & 0 & 253 & \\
\hline
\end{tabular}

EIF4EBP: elF-4E-binding protein; ppMAPkkk: partial putative mitogen-activated protein kinase kinase kinase; WHSC2: Wolf-Hirschhorn syndrome candidate 2 protein; UBE2V: ubiquitin-conjugated enzyme variant Kua; HNRPL: heterogeneous nuclear ribonucleoprotein L. PBMCs of HLA-A2 ${ }^{+}$gastric cancer patients were tested for their reactivity to a corresponding peptide after stimulation with each peptide. Values represent means of quadruplicate assays of IFN- $\gamma$ production (pg $\mathrm{ml}{ }^{-1}$ ) by the effector PBMCs in response to T2 cells pulsed with a corresponding peptide. Background IFN- $\gamma$ production in response to HIV peptide $\left(0-200\right.$ pg $\mathrm{ml}^{-1}$ ) was subtracted. Detectable levels of CTL-precursors were judged as positive (the score is in bold figures in Tables) if the mean value of IFN- $\gamma$ production by the peptide-stimulated PBMCs in response to a corresponding peptide was significantly $(P<0.05$, by two-tailed student $t$-test $)$ higher than that in response to HIV peptide. NT: Not tested.

or any of the negative peptides (SART3 $3_{315}, \mathrm{lck}_{486}, \mathrm{ART}_{13}$, and $\mathrm{ART}_{75}$ ) were not cytotoxic to any of the target cells tested. Similar results were obtained in the PBMCs of Pt 18 who had CTL-precursors reactive to EBV, SART3 ${ }_{109}, \mathrm{SART}_{315}$, and ART4 $_{75}$ (Figure $1 \mathrm{~A}$ and Table 3 ). PBMCs of Pt 35 (HLA-A2 ${ }^{+}$) possessed CTL-precursors reacting to Flu, EBV, SART3 302 , HNRPL $_{140}$ and the other five peptides (Table 2). Those PBMCs stimulated with $\mathrm{SART}_{302}$ and $\mathrm{HNRPL}_{140}$ also showed HLA-A2restricted and tumour-specific CTL activities (Figure 1B), whereas those stimulated with Flu, EBV, or any of the negative peptides had no CTL activity (data not shown). Similarly, PBMCs of Pt 39 had CTL-precursors reactive to Flu, EBV, and HNRPL peptides, and those stimulated with $\mathrm{HNRPL}_{501}$ peptide (Figure 1B), but not those with the other peptides (Flu, EBV, or negative peptides), showed HLA-A2-restricted and tumour-specific CTL activity. These CTL activities were inhibited by either anti-class I or -CD8 monoclonal antibody (mAb), but not by the other mAbs tested (data not shown). 
A
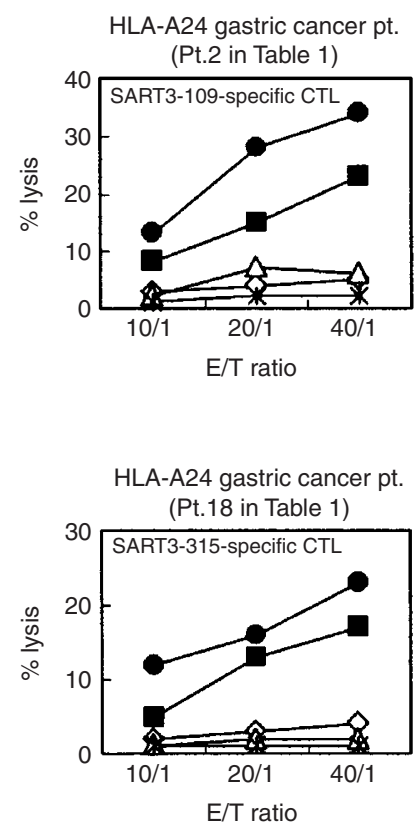
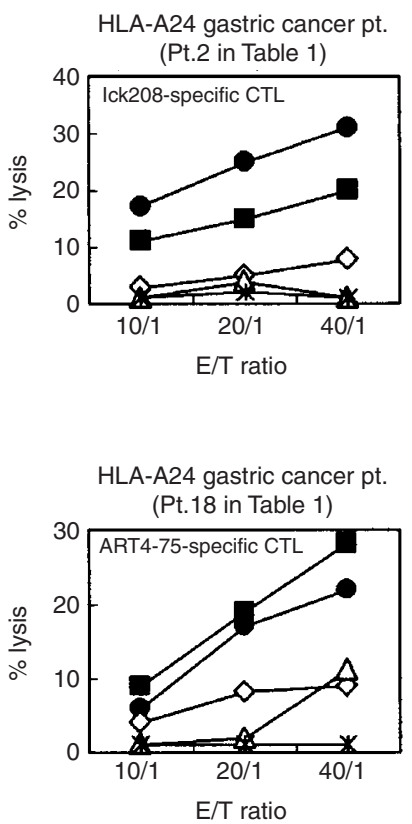

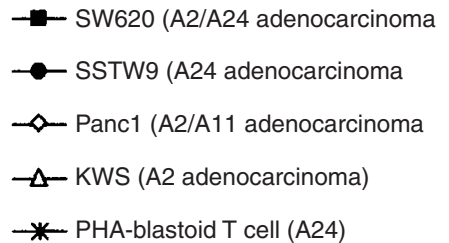

- PHA-blastoid T cell (A24)

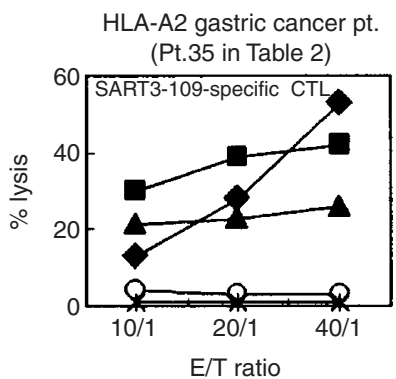

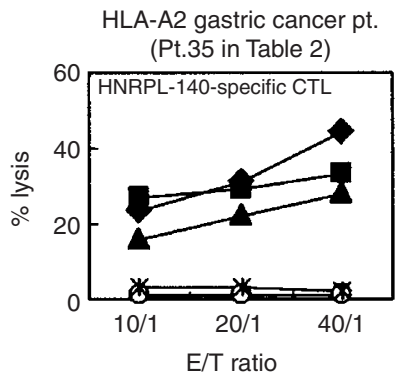

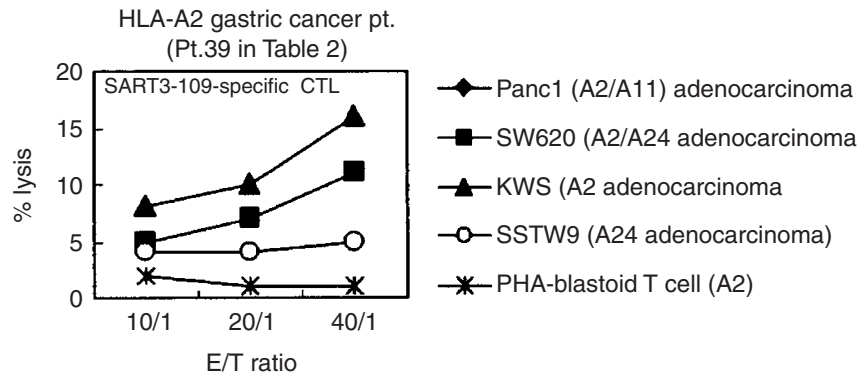

Figure I Peptide-induced CTL activity. PBMCs stimulated with peptides were expanded in the presence of feeder cells for $21-25$ days, and were tested for their cytotoxicity against various target cells by a $6 \mathrm{~h}^{51} \mathrm{Cr}$-release assay. Representative results of HLA-A24 $4^{+}$and $-\mathrm{A} 2^{+}$patients are shown in $(\mathbf{A})$ and $(\mathbf{B})$ respectively.

\section{CTL precursor frequency analysis}

A standard CTL precursor frequency analysis by limiting dilution method was performed in certain cases to compare the results obtained by the new culture method for CTL-induction. Representative results are shown in Figure 2. PBMCs of Pt 35 stimulated with EBV peptide by the new method were provided as a positive control at 400, 200,100, 50, 25 and 12.5 cells per well for CTLprecursor frequency analysis in duplicate assay. CTL-precursors were detectable in all 96 wells when cells were harvested from wells of 400 and 200 cells per well. CTL-precursors were detectable in 94, 88,77 and 30 wells when cells were harvested from wells of 100 , 50,25 and 12.5 cells per well (Figure $2 \mathrm{~A}$ ). Subsequently the CTL-frequency was evaluated as at least $>1$ out of 100 . Unstimulated PBMCs from the same patient were directly provided for CTL-precursor analysis in response to EBV and SART3 302 peptide to which CTL-precursors were detectable by means of our culture method (Pt 35 in Table 2). Precursor frequencies of EBV and SART3 $_{302}$ peptide-specific CTL were found to be one out of 2525 and one out of 7621, respectively (Figure 2B). Unstimulated PBMCs of Pt 2 were also provided for CTL-precursor analysis in response to SART3 ${ }_{109}, \mathrm{lck}_{208}$ and ART4 75 peptides. CTL-precursors to any of these three peptides were under detectable levels $(<1$ out of 26063) in this precursor frequency analysis. However, CTLprecursors reactive to the positive peptides $\left(\mathrm{SART} 3_{109}\right.$ and $\mathrm{lck}_{208}$ ) were found in one or two wells and no positive well was detected for the negative $\left(\mathrm{ART}_{45}\right)$ (Figure $2 \mathrm{C}$ ).

\section{CTL-precursors in other cancer patients and healthy donors}

The results of the induction assay regarding cancer patients other than those with gastric cancer are shown in Table 4 (HLA-A24 10 colon, 11 lung, seven gynecological, three prostate cancer, and four melanoma patients) and in Table 5 (HLA-A2 ${ }^{+}$five colon cancer patients). The same CTL-induction assay was also performed for 31 healthy donors (20 HLA-A $24^{+}$donors and 11

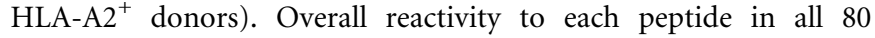
cancer patients and in 31 healthy donors is shown in Table 6. CTL-precursors reactive to at least one of the vaccine-candidatepeptides were detectable in 57 out of 80 patients $(71 \%)$, and the mean numbers of positive peptides were 2.0 peptides per positive 
Table 3 Cytotoxicity of peptide-stimulated CTLs from cancer patients

\begin{tabular}{|c|c|c|c|c|c|c|c|c|}
\hline Patient & Peptide & $\begin{array}{l}\text { Peptide-specific INF- } \gamma \\
\text { production }\left(\mathrm{pg} \mathrm{ml^{-1 }}\right)\end{array}$ & \multicolumn{6}{|c|}{ Cytotoxicity (\% lysis) } \\
\hline \multirow{5}{*}{ Patient 2} & SART3109 & 375 & 34 & 28 & $<5$ & $<5$ & $<5$ & $<5$ \\
\hline & SART $_{315}$ & 0 & $<5$ & $<5$ & $<5$ & $<5$ & $<5$ & $<5$ \\
\hline & $\mathrm{Ick}_{208}$ & 117 & 32 & 22 & $<5$ & $<5$ & $<5$ & $<5$ \\
\hline & $I^{\prime} k_{486}$ & 0 & $<5$ & $<5$ & $<5$ & $<5$ & $<5$ & $<5$ \\
\hline & $\mathrm{ART}_{75}$ & 0 & $<5$ & $<5$ & $<5$ & $<5$ & $<5$ & $<5$ \\
\hline \multirow[t]{5}{*}{ Patient 18} & EBV & 109 & $<5$ & $<5$ & $<5$ & $<5$ & $<5$ & $<5$ \\
\hline & SART3109 & 93 & 21 & 18 & $<5$ & $<5$ & $<5$ & $<5$ \\
\hline & $\mathrm{SART}_{315}$ & 102 & 24 & 18 & $<5$ & $<5$ & $<5$ & $<5$ \\
\hline & $\mid c k_{208}$ & 0 & $<5$ & $<5$ & $<5$ & $<5$ & $<5$ & $<5$ \\
\hline & $I^{\prime} k_{486}$ & 0 & $<5$ & $<5$ & $<5$ & $<5$ & $<5$ & $<5$ \\
\hline
\end{tabular}

Peptide-induced CTLs from PBMCs of cancer patients were tested for their cytotoxicity against various cells by standard $6 h^{5} \mathrm{Cr}$-release assay at E/T of $40 / \mathrm{l}$. Values represent means of triplicate assay.

A

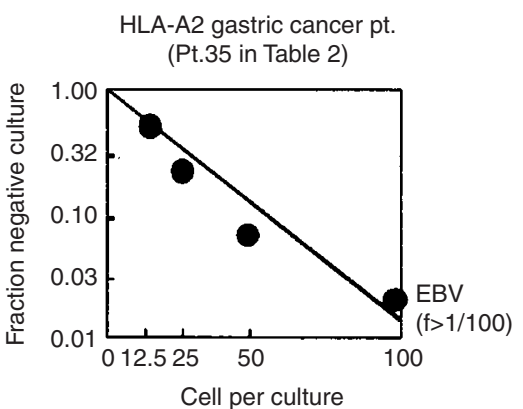

B

HLA-A2 gastric cancer pt. (Pt.35 in Table 2)

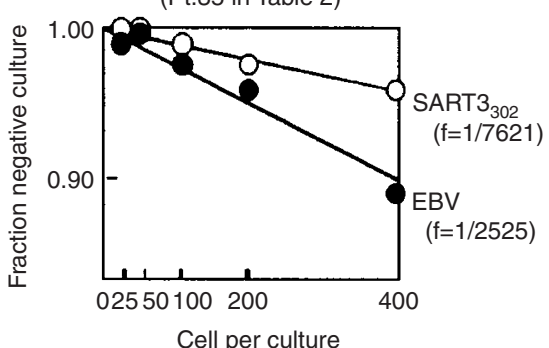

C

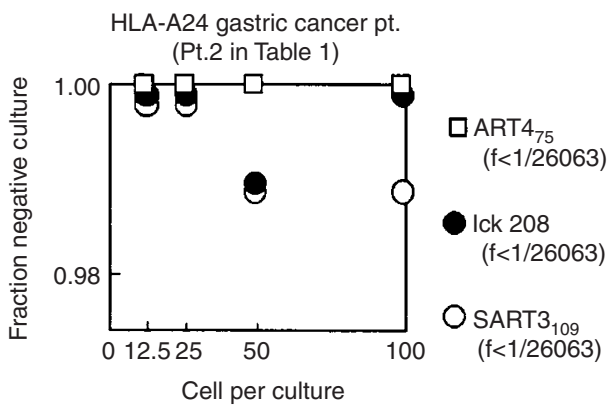

Figure 2 Precursor frequency analysis by limiting dilution method. PBMCs of a cancer patient (Pt 35) cultured with EBV peptide for 10 days by the new culture method $(\mathbf{A})$, unstimulated PBMCs of the same patient $(\mathbf{B})$ and unstimulated PBMCs of another cancer patient (Pt 2) (C) were served for limiting dilution culture as described in Materials and Methods. Cells from each well were tested at 9 to 15 days of culture for IFN- $\gamma$ production in the presence of target cells. Wells were considered positive if they contained effector cells producing much higher level $\left(>100 \mathrm{pg} \mathrm{ml}{ }^{-1}\right)$ and also statistically significant levels $(P<0.05$ by two-tailed Student- $t$ test) of IFN- $\gamma$ in response to CIR-A2402 or T2 cells pre-loaded with a corresponding peptide as compared with IFN- $\gamma$ levels in response to CIR-A2402 or T2 cells pre-loaded with HIV peptide in duplicate assay. Data were analysed by the minimum $\chi^{2}$ method with $95 \%$ confidence intervals, and the CTL precursor frequency was calculated by Taswell's method.

case (ranging from 1-8 peptides). A profile of the positive peptides of vaccine candidates varied among these 57 patients, and seemed not to be influenced by the cancer origin. CTL-precursors reacting to cancer-related peptides were also detectable in 20 out of 31 healthy donors $(64 \%)$, and the mean number of positive peptides in each donor was 1.4 (ranging from 1-4 peptides).

The percentages of detection of CTL-precursors reacting to foreign antigen peptide (Flu and EBV) in cancer patients were significantly lower than those in healthy donors in HLA-A24 cases (Table 6, left column). Those of EBV-specific CTL-precursors in cancer patients were also significantly lower than those in healthy donors in HLA-A2 cases (Table 6, right column). In contrast, the percentages of cases having CTL-precursors reactive to $\mathrm{SART}_{315}$ and $\mathrm{lck}_{488}$ peptides in HLA-A24 ${ }^{+}$patients were significantly higher than those in HLA-A24 ${ }^{+}$healthy donors (Table 6, left column). A similar trend was also observed in certain WHSC2and UBE2V-derived peptides in HLA-A2 ${ }^{+}$patients (Table 6 , right column).

\section{DISCUSSION}

We have demonstrated in the present study that peptide-specific CTL-precursors are detectable in the majority of cancer patients, and that PBMCs incubated with the positive peptides, not with the negative peptides, show significant levels of HLA-class-Irestricted cytotoxicity to cancer cells. These results suggest that vaccination of the positive peptides to cancer patients induces more potent anti-tumour response than that of the negative peptides.

Twenty-eight peptides (13 for HLA-A $24^{+}$and 15 for HLA-A2 ${ }^{+}$ cancer patients) were used in this study. There are, however, many other peptides that are vaccine candidates having the ability to induce HLA-class-I-restricted CTLs reactive to cancer cells. Therefore, increased numbers of peptides for the assay should lead to an increase in the number of patients having CTL-precursors reactive to peptides and in the number of positive peptides per patient. These two HLA-class I alleles (HLA-A24 and -A2) are observed in $>70 \%$ of Caucasians, $>80 \%$ of Asians, and $>40 \%$ of Blacks (Imanishi et al, 1992; Tokugawa et al, 1997). The present study also 
Table 4 Induction of peptide-specific CTLs from PBMCs of HLA-A24+ cancer patients (colon, lung, gynaecological, prostate, and melanoma)

\begin{tabular}{|c|c|c|c|c|c|c|c|c|c|c|c|c|c|c|c|c|c|c|c|c|c|}
\hline \multirow[b]{3}{*}{ Peptide } & \multicolumn{21}{|c|}{ Peptide-specific IFN- $\gamma$ production $\left(\mathrm{pg} \mathrm{ml}^{-1}\right)$} \\
\hline & \multicolumn{10}{|c|}{ HLA-A $24^{+}$colon cancer patients } & \multicolumn{11}{|c|}{ HLA-A24 ${ }^{+}$lung cancer patients } \\
\hline & Pt4l & Pt42 & Pt43 & Pt44 & Pt45 & Pt46 & Pt47 & Pt48 & Pt49 & Pt50 & Pt5 I & Pt52 & Pt53 & Pt54 & Pt55 & Pt56 & Pt57 & Pt58 & Pt59 & Pt60 & Pt6I \\
\hline Flu & 28 & 0 & 0 & 0 & 0 & 0 & 33 & 7 & 0 & 0 & 104 & 0 & 0 & 0 & 0 & 0 & 0 & 0 & 200 & 0 & 0 \\
\hline EBV & 231 & 8 & 0 & 0 & 29 & 0 & 0 & 0 & 0 & 63 & 49 & 0 & 0 & 62 & 0 & 0 & 38 & 10 & 188 & 0 & 0 \\
\hline SARTI 690 & 14 & 60 & 0 & 0 & 0 & 246 & 0 & 0 & 11 & 38 & 53 & 0 & 81 & 32 & 30 & 0 & 0 & 0 & 46 & 0 & 0 \\
\hline SART2 93 & 0 & 68 & 0 & 0 & 18 & 16 & 26 & 13 & 0 & 15 & 68 & 0 & 0 & 26 & 0 & 0 & 0 & 0 & 0 & 0 & 0 \\
\hline SART2 161 & 139 & 56 & 0 & 0 & 40 & 0 & 17 & 19 & 0 & 0 & 19 & 5 & 0 & 0 & 0 & 0 & 0 & 72 & 106 & 0 & 0 \\
\hline SART2 899 & 225 & 109 & 0 & 0 & 41 & 6 & 29 & 0 & 4 & 0 & 18 & 22 & 0 & 16 & 0 & 0 & 0 & 108 & 95 & 0 & 0 \\
\hline SART3 109 & 325 & 170 & 0 & 109 & 61 & 0 & 0 & 19 & 26 & $1500<$ & 0 & 297 & 0 & 0 & 0 & 0 & 0 & 125 & 0 & 0 & 0 \\
\hline SART3 315 & 17 & 104 & 0 & 0 & 45 & 0 & 39 & 0 & 26 & 15 & 108 & 77 & 0 & 0 & 0 & 0 & 0 & 87 & 0 & 0 & 126 \\
\hline CyB ${ }_{84}$ & 248 & 56 & 0 & 0 & 66 & 0 & 0 & 0 & 50 & $17 \mid$ & 35 & 217 & 0 & 0 & 198 & 0 & 59 & 30 & 19 & 0 & 0 \\
\hline $\mathrm{CyB}_{91}$ & 0 & 58 & 0 & 0 & 56 & 14 & 14 & 9 & 0 & 4 & III & 129 & 0 & 0 & 0 & 64 & 31 & 0 & 18 & 0 & 0 \\
\hline Ick 208 & 349 & 5 & 0 & 3 & 53 & 6 & 9 & 25 & 15 & 0 & 74 & 84 & 0 & 0 & 180 & 0 & 0 & 44 & 24 & 0 & 0 \\
\hline Ick 486 & 161 & 0 & 0 & 0 & 29 & 0 & 51 & 23 & 58 & 0 & 100 & 126 & 22 & 0 & 48 & 0 & 0 & 43 & 26 & 0 & 0 \\
\hline ICk 488 & 310 & 13 & 0 & 100 & 45 & 24 & 9 & 0 & 0 & 19 & 122 & 133 & 0 & 0 & 172 & 0 & 130 & 0 & 46 & 0 & 0 \\
\hline ART4 $_{13}$ & 0 & 0 & 0 & 0 & 64 & 7 & 29 & 0 & 70 & 0 & 114 & 105 & 10 & 0 & 50 & 0 & 130 & 0 & 26 & 0 & 0 \\
\hline ART4 75 & 0 & 21 & 0 & 0 & 59 & 0 & 6 & 0 & 25 & 0 & 122 & 128 & 7 & 0 & 0 & 0 & $1 / 3$ & 0 & 0 & 0 & 0 \\
\hline
\end{tabular}

Table 4 continued

\begin{tabular}{|c|c|c|c|c|c|c|c|c|c|c|c|c|c|c|}
\hline & \multicolumn{7}{|c|}{ HLA-A24 ${ }^{+}$gynaecological cancer patients } & \multicolumn{3}{|c|}{$\begin{array}{l}\text { HLA-A24 }^{+} \text {prostate } \\
\text { cancer patients }\end{array}$} & \multicolumn{4}{|c|}{ HLA-A24 ${ }^{+}$melanoma patients } \\
\hline & Pt62 & Pt63 & Pt64 & Pt65 & Pt66 & Pt67 & Pt68 & Pt69 & Pt70 & Pt7I & Pt72 & Pt73 & Pt74 & Pt75 \\
\hline EBV & 0 & 0 & 0 & 0 & 19 & 75 & 0 & 0 & 147 & 0 & 311 & 138 & 0 & 0 \\
\hline SARTI 690 & 67 & 14 & 0 & 142 & 21 & 0 & 33 & 0 & 0 & 0 & 7 & 0 & 0 & 0 \\
\hline SART2 93 & 30 & 0 & 0 & 112 & 175 & 16 & 9 & 0 & 0 & 0 & 0 & 0 & 0 & 0 \\
\hline SART3 $_{315}$ & 0 & 0 & 18 & 0 & 0 & 11 & 157 & 0 & 66 & 0 & 0 & 0 & 0 & 0 \\
\hline СуВ 84 & 20 & 6 & 0 & 4 & 0 & 0 & 0 & 14 & 0 & 0 & 0 & 0 & 0 & 0 \\
\hline CyB 91 & 0 & 0 & 0 & 0 & 0 & 0 & 0 & 0 & 0 & 0 & 16 & 0 & 0 & 0 \\
\hline Ick 208 & 0 & 0 & 13 & 0 & 318 & 0 & 76 & 0 & 0 & 0 & 0 & 0 & 0 & 0 \\
\hline Ick 486 & 2 & 0 & 0 & 0 & 250 & 0 & 0 & 0 & 0 & 0 & 69 & 0 & 0 & 0 \\
\hline Ick 488 & 0 & 7 & 172 & 0 & 142 & 0 & 0 & 76 & 0 & 0 & 0 & 0 & 0 & 0 \\
\hline
\end{tabular}

Sequence of each peptide is shown in Table I.

showed that the profile of positive peptides varies among patients, and that there is no obvious correlation regarding the types of cancers tested (gastric, colon, lung, gynaecological, and prostate cancers, and melanomas) or clinical stages (presence or absence of distant metastasis). Therefore, CTL-precursors reactive to peptides of vaccine candidates could be detectable in PBMCs of a large number of cancer patients throughout the world, regardless of cancer origin or clinical stage.

It is important to determine whether or not detection of peptide-specific CTL-precursors was associated with the expression of corresponding antigen in individual cancer patients. However, most epithelial cancer patients enrolled in this study were inoperable and availability of tumour samples was very limited in contrast to melanoma patients. In regard with SART-1, -2, -3, and ART4 antigens, we previously reported their protein expression in many samples of the majority of epithelial cancer cells and tissues by Western blot and Northern analyses (Shichijo et al, 1998; Yang et al, 1999; Nakao et al, 2000). We also reported that lck antigen was expressed in the majority of metastatic cancer cells and tissues (Harashima et al, 2001).
Difference in affinities of the peptides to the HLA-class I molecules might affect the efficacy of in vitro sensitization of PBMCs from cancer patients. In regard to peptides derived from either SART2 or SART3, their scores, an estimated half-time dissociation determined by computer program (Parker et al, 1994), were compared and it was found that peptides with higher scores seemed to induce peptide-specific CTLs more efficiently than those with lower scores (unpublished observation).

PBMCs from healthy donors also had CTL-precursors to peptides of vaccine candidates with relatively lower frequency, which was expected from our previous results showing that all the tumour-rejection antigens, from which the peptides originated, used in this study are non-mutated self-antigens preferentially expressed in proliferating cells, including malignant and normal cells (Yang et al, 1999). However, CTLs induced by these peptides showed cytotoxicity against cancer cells, but not against normal proliferating cells, as also demonstrated previously (Yang et al, 1999). Therefore, vaccination of these peptides may not be associated with adverse events in normal cells and normal tissues. Indeed, no severe adverse events have been observed in phase I clinical studies at the Kurume University Hospital, where 13 differ- 
ent peptides, also used in vitro in this study, have been used for HLA-A $24^{+}$cancer patients as peptides vaccines in vivo (Miyagi et al, 2001, and the other unpublished data).

Peptide-specific CTL-precursors were detected in healthy donors. One might wonder whether CTL-precursors of cancer patients are distinguishable from those of healthy donors or not. We observed that CyB peptide-stimulated CTLs from cancer patients had a tendency to show both peptide-specific and tumour-reactive responses, but those from healthy donors seemed to exhibit peptide-specific responses but no tumour-reactive response (Gomi et al, 1999). We suppose that, in healthy donors, CTL-precursors reacting to $\mathrm{CyB}$ peptides were primed as a result of cross-reactivity of $\mathrm{CyB}$ to bacteria-derived exogenous antigens (Ohkouchi et al, 2002). We also repeatedly reported that

Table 5 Induction of peptide-specific CTLs from PBMCs of HLA-A2 ${ }^{+}$ colon cancer patients

\begin{tabular}{|c|c|c|c|c|c|}
\hline \multirow[b]{3}{*}{ Peptide } & \multicolumn{5}{|c|}{ Peptide-specific IFN- $\gamma$ production $\left(\mathrm{pg} \mathrm{ml} \mathbf{~ m}^{-1}\right)$} \\
\hline & \multicolumn{5}{|c|}{ HLA-A ${ }^{+}$colon cancer patients } \\
\hline & Pt76 & Pt77 & Pt78 & Pt79 & Pt80 \\
\hline Flu & NT & 285 & 0 & 6 & 327 \\
\hline EBV & 0 & 134 & 0 & 0 & 0 \\
\hline SART3 302 & 19 & 8 & 0 & 0 & 0 \\
\hline SART3 309 & 140 & 7 & 17 & 0 & 50 \\
\hline CyB 129 & 9 & 7 & 0 & 0 & 0 \\
\hline CyB ${ }_{172}$ & 0 & 102 & 5 & 4 & 0 \\
\hline Ick 246 & 0 & 0 & 18 & 0 & 0 \\
\hline EIF4EBPI 51 & 0 & 30 & 230 & 0 & 9 \\
\hline ppMAPkkk 294 & 34 & 215 & 0 & 3 & 0 \\
\hline ppMAPkkk 432 & 61 & 14 & 35 & 189 & 0 \\
\hline WHSC2 103 & 33 & 7 & 14 & 5 & 0 \\
\hline WHSC2 I4। & 26 & 30 & 9 & III & 0 \\
\hline${\text { UBE} 2 V_{43}}_{4}$ & 0 & 0 & 147 & 0 & 0 \\
\hline UBE2V $_{85}$ & 0 & 0 & 0 & 0 & 0 \\
\hline 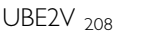 & NT & 0 & 108 & 12 & 0 \\
\hline HNRPL 140 & 10 & 0 & 122 & 10 & 0 \\
\hline HNRPL 501 & 0 & 0 & 0 & 7 & 0 \\
\hline
\end{tabular}

Sequence of each peptide is shown in Table 2. peptide-stimulated PBMCs from certain healthy donors produced significant levels of IFN- $\gamma$ in response to peptides, but rarely showed cytotoxicity against tumour cells in an HLA-A24 or -A2 restricted manner by means of a ${ }^{51} \mathrm{Cr}$-release assay (Harashima et al, 2001; Ito et al, 2000, 2001; Kawano et al, 2000; Nishizaka et $a l, 2000)$. In addition, peptide-specific CTLs from cancer patients proliferated well for a long time in culture with IL-2 alone and thus these expanded cells became available in use for a ${ }^{51} \mathrm{Cr}$-release assay, whereas those from healthy donors did not (unpublished data). Therefore, measurement of CTL activity with a standard ${ }^{51} \mathrm{Cr}$-release assay could be a good tool to distinguish CTL-precursors of cancer patients from those of healthy donors.

There is a possibility that vaccination with a given peptide could result in in vivo immunoselection of host tumour in situ, and that further boosting against such epitopes might be unsuccessful. Jager et al (1996) reported an inverse correlation of antigen expression and CTL response in patients with metastatic melanoma (Jager et $a l, 1996)$. However, as described in the Introduction, we undertook this study to determine whether CTL precursors were detectable at the prevaccination state, based on the idea that boosting of circulating CTL precursors could be more reasonable than newly priming of CTLs. We suppose that an appropriate clinical trial is needed to answer to this key question. A phase I study of CTLprecursor-oriented vaccine, in which prevaccination PBMCs were screened in vitro for their reactivity to each of the peptides followed by vaccination of only the positive peptides, has been in progress since November 2000 at Kurume University. The initial study of immune responses to both peptides and tumour cells in post-vaccination PBMCs of colorectal cancer patients suggested that the present regime could be superior to the conventional regime to elicit prompt and strong immune responses.

CTL-precursors detected by this new culture method were also detectable by the standard CTL-precursor analysis in the Pt 35 case, but not in the Pt 2 case. Therefore, the limit of sensitivity of the new method may be higher than that of the conventional CTL-precursor frequency analysis. PBMCs were stimulated five or 0 times before the assay by the new method or by CTL-precursor frequency analysis, respectively, which might have influenced the limit of sensitivity. The limit of sensitivity of the standard CTL-precursor analysis is one out of 26063 (Taswell, 1981), whereas the limit of sensitivity of the new method used in this study is one out of 100000 (Hida et al,

Table 6 Percentage of peptide-specific CTL-induction

Positive percentage of induction of peptide-specific CTLs (\%)

\begin{tabular}{|c|c|c|c|c|c|c|c|}
\hline & \multicolumn{3}{|c|}{ HLA-A24-restricted peptides } & & \multicolumn{3}{|c|}{ HLA-A2-restricted peptides } \\
\hline $\begin{array}{l}\text { Flu } \\
\text { EBV }\end{array}$ & $\begin{array}{l}14 \text { ( } 4 \text { out of } 55) \\
16 \text { (9 out of } 55)\end{array}$ & $\begin{array}{l}\leftarrow P<0.05 \rightarrow \\
\leftarrow P<0.01 \rightarrow\end{array}$ & $\begin{array}{l}40 \text { ( } 8 \text { out of } 20) \\
65 \text { (13 out of } 20)\end{array}$ & $\begin{array}{l}\text { Flu } \\
\text { EBV }\end{array}$ & $\begin{array}{l}53 \text { (9 out of 17) } \\
29 \text { (7 out of } 24)\end{array}$ & $\leftarrow P<0.05 \rightarrow$ & $\begin{array}{l}80 \text { (8 out of } 10) \\
72(8 \text { out of } 11)\end{array}$ \\
\hline $\begin{array}{l}\text { SARTI }_{690} \\
\text { SART2 }_{93} \\
\text { SART2 }_{161} \\
\text { SART2 }_{899} \\
\text { SART3 }_{109} \\
\text { SART3 }_{315} \\
\text { CyB }_{84} \\
\text { CyB }_{91} \\
\text { Ick }_{208} \\
\text { Ick }_{486} \\
\text { Ick }_{488} \\
\text { ART4 } 13 \\
\text { ART4 45 }\end{array}$ & $\begin{array}{l}9 \text { (5 out of } 55) \\
7(4 \text { out of } 55) \\
16 \text { (9 out of } 55) \\
18(10 \text { out of } 55) \\
27(15 \text { out of } 55) \\
19 \text { ( } 10 \text { out of } 55) \\
16 \text { (9 out of } 55) \\
7(4 \text { out of } 55) \\
18 \text { ( } 10 \text { out of } 55) \\
15(8 \text { out of } 55) \\
24 \text { ( } 13 \text { out of } 55) \\
16 \text { ( } 9 \text { out of } 55) \\
22 \text { ( } 12 \text { out of } 55)\end{array}$ & $\leftarrow P<0.05 \rightarrow$ & 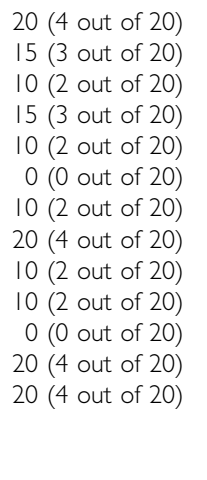 & $\begin{array}{l}\text { SART3 }_{302} \\
\text { SART3 }_{309} \\
\text { CyB }_{129} \\
\text { CyB }_{172} \\
\text { ICk }_{246} \\
\text { EIF4EBPI }_{51} \\
\text { PpMAPKkk }_{294} \\
\text { PPMAPkkk }_{432} \\
\text { WHSC2 }_{103} \\
\text { WHSC2 }_{141} \\
\text { UBE2V }_{43} \\
\text { UBE2V }_{85} \\
\text { UBE2 }_{208} \\
\text { HNRPL }_{140} \\
\text { HNRPL }_{501}\end{array}$ & $\begin{array}{l}13(3 \text { out of } 24) \\
21(5 \text { out of } 24) \\
10(2 \text { out of } 21) \\
8(2 \text { out of } 24) \\
8(2 \text { out of } 25) \\
17(3 \text { out of } 18) \\
10(2 \text { out of } 21) \\
5(1 \text { out of } 21) \\
10(2 \text { out of } 21) \\
10(2 \text { out of } 21) \\
14(3 \text { out of } 21) \\
10(2 \text { out of } 21) \\
17(2 \text { out of } 12) \\
24(5 \text { out of } 21) \\
5((\mid \text { out of } 21)\end{array}$ & & 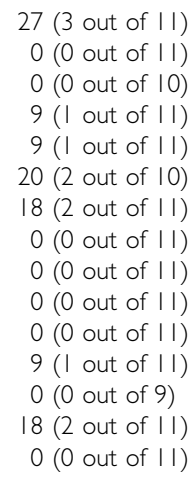 \\
\hline
\end{tabular}

Fisher's exact probability test was used for statistical analysis between cancer patients and healthy donors. 
2002). The specificity and positive predictive value of the CTL induction system used in this study were found to be high enough for clinical use (90 and 100\%, respectively) (data not shown). The CTL induction method used in this study also has some other advantages compared to the standard CTL-precursor analysis or the tetramer method. The cost of the standard CTL-precursor analysis is more than 10 times that of the method used in this study (approximately $\$ 500 v s \$ 30$, per peptide, respectively), and the standard CTL-precursor analysis requires large number of feeder cells so that the influence of allogeneic feeder cells may not be entirely excluded. Although a tetramer assay is an alternative method, it does not directly reflect the functional activity of CTLs such as that reflected by cytotoxicity or cytokine production.

In conclusion, this study has showed that peptide-specific CTLprecursors are detectable in PBMCs of cancer patients prior to vaccination, thus providing a scientific basis for the development

\section{REFERENCES}

Amara RR, Villinger F, Altman JD, Lydy SL, O'Neil SP, Staprans SI, Montefiori DC, Xu Y, Herndon JG, Wyatt LS, Candido MA, Kozyr NL, Earl PL, Smith JM, Ma HL, Grimm BD, Hulsey ML, Miller J, McClure HM, McNicholl JM, Moss B, Robinson HL (2001) Control of a mucosal challenge and prevention of AIDS by a multiprotein DNA/MVA vaccine. Science 292: $69-74$

Bruggen P, Traversari C, Chomez P, Lurquin C, Plaen ED, Eynde BD, Knuth A, Boon T (1991) A gene encoding an antigen recognized by cytotoxic $T$ lymphocytes on a human melanoma. Science 254: 1643-1647

Correale P, Walmsley K, Zaremba S, Zhu SZ, Schlom J, Tsang KY (1998) Generation of human cytotoxic $\mathrm{T}$ lymphocyte lines directed against prostate-specific antigen (PSA) employing a oligoepitope peptide. J Immunol 161: $3186-3194$

Finn OJ, Lotze MT (2001) A decade in the life of tumour immunology. Clin Cancer Res 7: 759s-760s

Fisk B, Blevins TL, Wharton J, Ioannides C (1995) Identification of an immunodominant peptide of HER2/neu proto-oncogene recognized by ovarian tumour specific cytotoxic T lymphocytes lines. J Exp Med 181: 2109-2114

Gajewski TF, Fallarino F, Ashikari A, Sherman M (2001) Immunization of HLA-A2 ${ }^{+}$melanoma patients with MAGE-3 or MelanA peptide-pulsed autologous peripheral blood mononuclear cells plus recombinant human interleukin 12. Clin Cancer Res 7: 895s-901s

Gomi S, Nakao M, Niiya F, Imamura Y, Kawano K, Nishizaka S, Hayashi A, Sobao Y, Oizumi K, Itoh K (1999) A cyclophilin B gene encodes antigenic epitopes recognized by HLA-A24-restricted and tumour-specific cytotoxic T lymphocytes. J Immunol 163: 4994-5004

Harashima N, Tanaka K, Sasatomi T, Shimizu K, Miyagi Y, Yamada A, Tamura M, Yamana H, Itoh K, Shichijo S (2001) Recognition of the Lck tyrosine kinase as a tumour antigen by cytotoxic $\mathrm{T}$ lymphocytes of cancer patients with distant metastases. Eur J Immunol 31: 323-332

Hida N, Maeda Y, Katagiri K, Takasu H, Harada M, Itoh K (2002) A simple culture protocol to detect peptide-specific cytotoxic T lymphocyte precursors in the circulation. Cancer Immunol Immunother 51: 219-228

Imanishi T, Akaza T, Kimura A, Tokunaga K, Gojobori K (1992) Allele and haplotype frequencies for HLA and complement loci in various ethnic groups. In HLA Tsuji K, Aizawa M, Sasazuki T. (ed) pp 1065-1066 Oxford: Scientific Publication

Ito M, Shichijo S, Miyagi Y, Kobayashi T, Tsuda N, Yamada A, Saito N, Itoh K (2000) Identification of SART3-derived peptides capable of inducing HLA-A2-restricted and tumour-specific CTLs in cancer patients with different HLA-A2 subtypes. Int J Cancer 88: 633-639

Ito M, Shichijo S, Tsuda N, Ochi M, Harashima N, Saito N, Itoh K (2001) Molecular basis of $\mathrm{T}$ cell-mediated recognition of pancreatic cancer cells. Cancer Res 61: 2038-2046

Jager E, Ringhoffer M, Karbach J, Arand M, Oesch F, Knuth A (1996) Inverse relationship of melanocyte differentiation antigen expression in melanoma tissues and $\mathrm{CD}^{+}$cytotoxic-T-responses: evidence for immunoselection of antigen-loss variants in vivo. Int J Cancer 66: 470-476

Janeway CA, Travers P, Walport M, Capra JD (1999) T-cell activation is initiated when recirculating $\mathrm{T}$ cells encounter specific antigen in draining lymphoid tissue. In Immuno Biology 4th edn, Austin P, Lawrence E (ed) pp 391-393 New York: Current Biology Publications and Garland Publishing of a CTL-precursor-oriented peptide vaccine as an order-made cancer immunotherapy for the majority of cancer patients throughout the world. The same vaccine strategy may be applicable to patients infected with HIV or other pathogenic viruses, for which no effective vaccine is available.

\section{ACKNOWLEDGEMENTS}

This work was supported in part by grants from The Ministry of Education, Science, Sport, Culture, and Technology of Japan (11178101 to K Itoh), and from The Ministry of Health, Labor, and Welfare of Japan (H2-genome-003, 11-16, and H12-cancer004 to K Itoh).
Kaech SM, Ahmed R (2001) Memory CD8 ${ }^{+} \mathrm{T}$ cell differentiation: initial antigen encounter triggers a developmental program in naïve cells. Nature Immunol 2: 415-422

Kawakami Y, Eliyahu S, Sakaguchi K, Robbins PF, Rivoltini L, Yannelli JR, Appella E, Rosenberg SA (1994) Identification of the immunodominant peptides of MART-1 human melanoma antigen recognized by the majority of HLA-A2 restricted tumour infiltrating lymphocytes. J Exp Med 180: $347-351$

Kawano K, Gomi S, Tanaka K, Tsuda N, Kamura T, Itoh K, Yamada A (2000) Identification of a new endoplasmic reticulum-resident protein recognized by HLA-A24-restricted tumour infiltrating lymphocytes of lung cancer. Cancer Res 60: $3550-3358$

Marchand M, Baren VB, Weynants P, Brichard V, Dreno B, Tessier MH, Rankin E, Parmiani G, Arienti F, Humblet Y, Bourlond A, Vanwijck R, Lienard D, Beauduin M, Dietrich PY, Russo V, Kerger J, Masucci G, Jager E, Greve JD, Atzpodien J, Brasseur F, Coulie PG, Bruggen P, Boon T (1999) Tumor regressions observed in patients with metastatic melanoma treated with an antigen peptide encoded by MAGE-3 and presented by HLA-A1. Int I Cancer 80: 219-230

Miyagi Y, Imai N, Sasatomi T, Yamada A, Mime T, Katagiri K, Nakagawa M, Muto A, Okouchi S, Isomoto H, Shirouzu K, Yamana H, Itoh K (2001) Induction of cellular immune responses to tumour cells and peptides in colorectal cancer patients by vaccination of SART3 peptides. Clin Cancer Res 7: 3950-3962

Nakao M, Shichijo S, Imaizumi T, Inoue Y, Matsunaga K, Yamada A, Kikuchi M, Tsuda N, Ohta K, Takamori S, Yamana H, Fujita H, Itoh K (2000) Identification of a gene coding for a new squamous cell antigen recognized by the CTL. I Immunol 165: 2565-2574

Nishizaka S, Gomi S, Harada K, Oizumi K, Itoh K, Shichijo S (2000) A new tumour-rejection antigen recognized by cytotoxic $\mathrm{T}$ lymphocytes infiltrating into a lung adenocarcinoma. Cancer Res 60: 4830-4837

Ohkouchi S, Yamada A, Imai N, Mine T, Harada K, Shichijo S, Maeda Y, Saijo Y, Nukiwa T, Itoh K (2002) Non-mutated tumour-rejection antigen peptides elicit type-I allergy in the majority of healthy donors. Tissue Antigen 59: $259-272$

Parker KC, Bednarek MA, Coligan JE (1994) Scheme for ranking potential HLA-A2binding peptides based on independent binding of individual peptide side-chains. J Immunol 152: 163-175

Rosenberg SA, Yang JC, Schwartzentruber DJ, Hwu P, Marincola FM, Topalian SL, Restifo NP, Dudley ME, Schwarz SL, Spiess PJ, Wunderlich JR, Prakhurst MR, Kawakami Y, Seipp CA, Einhorn JH, White DE (1998) Immunologic and therapeutic evaluation of a synthetic peptide vaccine for the treatment of patients with metastatic melanoma. Nature Med 4: $321-327$

Shichijo S, Nakao M, Imai Y, Takasu H, Kawamoto M, Niiya F, Yang D, Toh Y, Yamana H, Itoh K (1998) A gene encoding antigenic peptides of human squamous cell carcinoma recognized by cytotoxic T lymphocytes. J Exp Med 187: 277-288

Stipdonk MJB, Lemmens EE, Schoenberger SP (2001) Naïve CTLs require a single brief period of antigenic stimulation for clonal expansion and differentiation. Nature Immunol 2: 423-429 
Tamura M, Nishizaka S, Maeda Y, Ito M, Harashima N, Harada M, Shichijo S, Itoh K (2001) Identification of cyclophilin B-derived peptides capable of inducing histocompatibility leukocyte antigen-A2-restricted and tumourspecific cytotoxic T lymphocytes. Jpn J Cancer Res 92: 762-767

Taswell C (1981) Limiting dilution assays for the determination of immunocompetent cell frequencies. J Immunol 126: 1614-1619

Tokugawa $\mathrm{K}$, Ishikawa $\mathrm{Y}$, Ogawa $\mathrm{A}$, Wang $\mathrm{H}$, Matsunaga S, Moriyama S (1997) Sequence-based association analysis of HLA class I and II alleles in Japanese supports conservation of common haplotypes. Immunogenetics 46: $199-205$
Wang F, Bade E, Kuniyoshi C, Spears L, Jeffery G, Marty V, Groshen S, Weber J (1999) Phase I trial of a MART-1 peptide vaccine with incomplete freund's adjuvant for resected high-risk melanoma. Clin Cancer Res 59: $4056-4060$

Yang D, Nakao M, Shichijo S, Sasatomi T, Takasu H, Matsumoto H, Mori K, Hayashi A, Yamana H, Shirouzu K, Itoh K (1999) Identification of a gene coding for a protein possessing shared tumour epitopes capable of inducing HLA-A-24-restricted cytotoxic $\mathrm{T}$ lymphocytes in cancer patients. Cancer Res 59: 4056-4063 